\title{
Affective Wellbeing and the Teaching of Music in Ghanaian Basic Schools: A Reflection
}

\author{
Eric Debrah Otchere \\ Lecturer, Department of Music and Dance, \\ University of Cape Coast, Ghana \\ eric.otchere@ucc.edu.gh \\ Isaac Richard Amuah \\ Associate Professor, Department of Music and Dance, \\ University of Cape Coast, Ghana \\ iamuah@ucc.edu.gh \\ Margaret Delali Numekevor \\ Assistant Lecturer, Department of Music and Dance, \\ University of Cape Coast, Ghana \\ delali.numekevor@ucc.edu.gh
}

Received: June 18, 2016 / Accepted: August 20, 2016 / Published: December 16, 2016

\begin{abstract}
Any healthy education aims to develop the individual holistically. To help achieve and assess this goal, educational objectives have been categorized under three domains: cognitive, psychomotor and affective. The arts (music particularly), have been identified as being best suited for the training of the affective domain. Using a number of instruments and triangulation methods, we examined this claim. We observed that music teaching in Ghanaian basic schools has, to a large extent, not fulfilled this mandate. We recommend the need to rethink the music program in two main ways: a) reviewing curricula materials and b) providing requisite training for music teachers.
\end{abstract}

Keywords: affective wellbeing, cognitive, education, music, psychomotor

The taxonomization of educational objectives into different domains (Simpson, 1966; Krathwohl, Bloom \& Masia, 1964; Bloom, 1956) is predicated on the need to offer adequate training to the different facets that cumulatively contribute to the total development of the individual who can be justly labelled as "well-educated". In any formal educational system, there is a perennial challenge of many subjects competing for attention on the time table (Murphy \& Fautley, 2015). Apparently, each of these subjects essentially has unique values which it offers towards the development of the students. It is the convincing articulation of this unique value(s) that underpins the advocacy for the inclusion of the subject on the time table. The acceptance of many different subjects with their corresponding individualistic values, is a firm testament to the claim that different aspects of humans need developing. This idea is, in fact, nothing new as it goes back into history. In Aristotle's Politics for example, he unequivocally expresses the 
futility in an education that trains only the mind and not the heart. It is evident in Aristotle's concern that any education worth its salt should extend beyond the development of cognitive abilities to encompass other areas of importance. Rainbow (1989) sheds some considerable light on the foregoing through his description of ancient Greek educational practice. Among other things, he identifies three basic components of humans that the ancient Greeks endeavored to train: the head, the hands and the heart (the $3 \mathrm{H}$ ) - which corresponded respectively to the mind, the body and the soul. Some of the earliest subjects that were believed to help train the 3H were: arithmetic (for the mind), gymnastics (for the body) and music (for the soul). Thus, Platonian and Aristotelian discourse, as well as, writings of other philosophers of the time, is replete with references to the inextricable connection between music and moral behaviour since the heart was believed to be the seat of morality and music was meant to educate it.

In a number of ways, it is reasonable to state that modern educational structure has borrowed extensively from the ancient Greeks. The training of the $3 \mathrm{H}$ (head, hand and heart) undoubtedly was later became captured by modern terminology as 'the three domains': cognitive (mind), psychomotor (hands) and affective (heart). Best practices in education require that each of these domains is catered for in the teaching of every lesson, irrespective of the subject (Anderson \& Krathwohl, 2001; Chauhan, 1991). However, the fact that certain subjects are more suited for developing particular domains has also been firmly established ipso facto (Otchere, 2014; Otchere, 2013a; Flolu, 2000; Abeles, Hoffer \& Klotman, 1995; Horley \& Brian, 1985). On the whole, it appears that while subjects within the hard sciences are more oriented towards the cognitive domain, Physical and Vocational education subjects rank high in the training of the psychomotor domain. The Arts and Social Sciences (encompassing subjects that fall under the general tag of "Humanities") have been argued several times to be more suited for the development of the affective domain (Otchere, 2013b; Jager, 2009; Anamuah-Mensah, AsabereAmeyaw \& Dennis, 2007; Reimer, 2003; Goodhart, Verdi, \& Kennedy, 1991; Akrofi, 1982).

Regarding the quality of education required to develop a healthy affect, scholars in the field of aesthetic education and transformative emotional intelligence have concluded that arts education is critical to the education of human subjectivity, feeling, or affect (Reimer, 2009; Reimer, 2003; Meyer, 1956). Within the Arts and Humanities however, the Performing Arts (including Music, Dance and Drama) have often been identified as subjects that are very effective in the development of the affective domain. From philosophical observations by ancient Greek thought leaders to empirically (scientifically) based findings of contemporary researchers, convincing arguments have been produced in support of the strong relationships among music/dance, affective health, and physical wellbeing (Otchere, 2015; Valentine, Jayne, \& Gould, 2014; Bilderback \& Woelfel, 2012; Braun, 2008; Miles, 2005; Barlow, 1977). This forms the aegis under which we proceed in our current study. We define a healthy education as one that makes provision for the equitable development of these three domains. We focus specifically, however, on the affective domain and explore the extent to which the teaching of Music in Ghanaian basic schools fulfils one of its greatest mandates of consciously aiming for the development of this domain.

According to Abeles, Hoffer and Klotman (1995), "the affective outcomes of instruction clearly do not receive the same priority as do the cognitive results of instruction in today's schools" (p. 237). They further note that, "this is as true in music as in other disciplines, and yet the music education profession has tended to cite goals that seem to include the affective domain as a primary support for including music in the schools" (p. 237). To exemplify the point about citing affective goals as the basis for including music in education, the following general aims and general objectives are legibly spelled out for the teaching of the Creative Arts 
(the subject within which music is encapsulated in Ghanaian basic schools) in the preliminary pages of the Creative Arts syllabus for Ghanaian Basic Schools (levels $1-3$ and 4-6).

General aims - develop human and moral values such as tolerance, sharing, helping, concentration, discipline, self-confidence, co-operation, honesty, selfawareness, self-expression teamwork and sense of judgment (p. iii).

General Objectives - pupils will:

1. acquire basic knowledge, skills and values through Performance, Composition and Two-Dimensional Art Activities such as picture making, print and patternmaking.

2. develop skills in critical, independent thinking, reasoning and imagination.

3. acquire skills in self-expression.

4. appreciate products of artists/artistes and beauty in the environment.

5. recognize the importance of appreciating beauty in the environment and works of artists/artistes (pp. iii - iv).

It emerges quite clearly from the general aims and objectives that the utmost essence of the Creative Arts in Ghanaian basic schools dwells in its perceived and proven ability to develop aspects of the individual which largely fall within the affective domain such as, the development of value systems (tolerance, self-expression, value judgment, honesty, team-work, etc.), vivid imagination, appreciation and the like. Otchere (2013) argues that "the important point in education is the inculcation of desirable values and the achievement of positive outcomes" ( $p$. 22). Taking necessary steps to achieve the goals spelled out above will therefore mean that the general goals for education in general, can be achieved through the teaching of the Creative Arts. In the words of Reimer (1989), "every field in education is obligated to explain its values to itself and to others and to have a plan for how those values can be gained through schooling" (p. 214). The values that have often been advanced for the field of the Creative Arts, as exemplified above, are those that principally revolve around the nurturing of the affective domain. The Creative Arts syllabus for Ghanaian basic schools, however, is made up of different components: performing arts (music, storytelling, drama, dance) and the visual/fine art (painting, picture making, sewing). In this study, our emphasis is on the music component of the Creative Arts syllabus and the extent to which its teaching and learning contribute to the achievement of the affective goals spelled out in the syllabus.

\section{Affective Wellbeing and the Affective Domain}

In this study, we use "Affective Wellbeing" as a variable of interest to imply the result of the extent to which the affective domain is consciously isolated and systematically addressed through the teaching and learning of Music/Dance in Ghanaian basic schools. It is significant to note that in practical terms, such isolation does not actually happen. As Piaget points out (in Derry and Murphy 1986, p. 29), "at no level, at no state, even in the adult, can we find a behaviour or a state which is purely cognitive without affect nor a purely affective state without a cognitive element involved". The implication of this statement is illuminated by McLeod (1987) who asserts that "while we might examine cognition and affect separately, we should 
think about these processes holistically, since that is how they operate" (p. 427) ${ }^{1}$ Being fully aware of the futility in separating the domains, we deviate from a cussed stance and adopt a theoretical model that supports the conceptualization of the domains as a unitary entity. Therefore, the isolation of the affective domain in this study is only for analytical and discussion purposes. What we are looking out for, are multiple indicators that show that the affective domain is a major area of attention as far as the teaching and learning of Music are concerned.

Our use of the term "affective" is in line with that of McLeod (1986) who equates it to the domain of emotions and feelings that can vary in intensity from "cold" (preferences, moods, attitudes, where the organism is not highly aroused) to "hot" (emotional states characterized by activation of the autonomic nervous system-tense muscles, increased heartbeat, sweaty palms). They also can vary in direction, from positive to negative. This stance on the affective domain finds corroboration in Krathwohl et al. (1964) who add a few more qualities such as interests, appreciations, attitudes and values of the individual. The available literature shows a panoply of research findings that confirm the educability of affect and for that matter human feeling. It also establishes the correlation between a healthy affect/human subjectivity and quality education. In a number of ways, it is the domain that makes us essentially human - leading us beyond just thinking beings to making us feeling beings as well. The importance of this domain, particularly in education, has been adequately stressed by many scholars, a few being Farmer (1986), Brand (1986), and Norman (1981). In the subsequent paragraphs under this sub-topic however, it is our intention to spend a little more time to focus on the indicators and categories of the affective domain.

Krathwohl et al. (1964) have expended enormous energies to create a comprehensive typology of the affective domain. This typology runs from receiving through responding, valuing and organization to characterization by a value or value complex, with subcategories in all categories except the last. Table 1 is an adaptation Krathwohl et al.'s taxonomy of the affective domain as cited in Abeles, Hoffer and Klotman (1995). The categories as specified in the table are hierarchical with receiving being the lowest affective category and characterization by a value or value complex being the highest affective category. To be able to monitor and examine these affective categories within educational practice, a number of verbs (mostly behavioral) have been suggested that indicate the emphasis on each of these categories in the statement of lesson objectives, teaching activities and evaluative sentences. These verbs constitute the basis of analysis in the curriculum materials assembled for this study.

\section{Table 1: Krathwohl et al.'s taxonomy of affective domain}

1. Receiving This involves behaviours such as being aware of phenomena or stimuli and being willing to take notice of them. "Capturing" a student's attention illustrates this level. It is a prerequisite behaviour for the other levels.

2. Responding Here, the student is not only aware of stimuli, but is interacting with them. This may take the form of complying with a set of rules, seeking out additional information on a topic, or finding pleasure in participating in an activity.

3. Valuing A student who demonstrates valuing behaviour is one who has attached worth or value to an object, phenomenon, or behaviour. Although this

\footnotetext{
${ }^{1}$ For a further discussion of this inseparability claim between the domains, see Wellington (2010) and Vygotsky (1962).
} 
4. Organization $\quad$ Interrelating values and the beginning of an organized value system are behaviours that characterize this level. It includes consideration of the consistency and stability of values and beliefs that evolve into a value complex.

5. Characterization At this level of the domain the student's behaviour reflects a conby a value or value complex. sistency. This characteristic behaviour or life style is due to the internalization of a value or value system to the extent that it is readily observable.

In Table 2, some of the verbs are listed against their corresponding categories. It must also be noted that because learning objectives are further defined by modifiers and the objects that follow the verbs, some of the verbs may be found as belonging to more than one level of the affective categories. Pacansky-Brock (2012) provides other traits that students may exhibit at each of the levels. At the level of receiving, he notes that students may listen to the comments of peers and attend to other details within their immediate environment. The learner is sensitized to the existence of certain phenomena. It includes awareness, willingness to receive, and controlled or selected attention. At the level of responding, students may leave unique comments that contribute to the development of a conversation. There is active participation on the part of the learner as s/he reacts and attends to a particular phenomenon. Learning outcomes may emphasize compliance with responding, willingness to respond, or satisfaction in responding (motivation). Then, at the level of valuing, they may share perspectives while respecting the diverse opinions of the group. It reflects the worth or value a person attaches to a particular object, phenomenon, or behaviour. It ranges from simple acceptance to a more complex state of commitment. Valuing is based strongly on the internalization of a set of specified values, while clues to these standards are expressed in the learner's overt behavior and are often identifiable. At the organizing level, students may accept different viewpoints; build upon them to develop new perspectives and understanding of ideas. Values are sorted into priorities by contrasting different values, resolving conflicts between them, and creating unique value systems. The emphasis is on comparing, relating, and synthesizing values. At the highest level (internalizing values) or characterization, the student already has a value system that controls behavior. The behavior is pervasive, consistent, predictable, and most importantly, characteristic of the learner. Instructional objectives are concerned with the student's general patterns of adjustment (personal, social, emotional). Students cooperatively collaborate with group members towards the achievement of positive outcomes.

Table 2: Sample affective verbs

\begin{tabular}{ll}
\hline Level of affective domain & \multicolumn{1}{c}{ Sample verbs } \\
\hline Receiving & $\begin{array}{l}\text { ask, choose, describe, follow, give, hold, identify, locate, } \\
\text { name, point to, select, use, erect, reply, accept, attend, de- } \\
\text { velop, realize }\end{array}$ \\
\hline Responding & $\begin{array}{l}\text { answer, assist, aid, comply, conform, discuss, greet, help, la- } \\
\text { bel, perform, practice, present, read, recite, report, select, tell, } \\
\text { write, behave, complete, obey, observe }\end{array}$ \\
\hline Valuing & $\begin{array}{l}\text { complete, demonstrate, differentiate, explain, form, follow, } \\
\text { initiate, invite, propose, join, justify, report, share, work, se- } \\
\text { lect, balance, believe, influence, prefer, pursue, value }\end{array}$ \\
\hline
\end{tabular}




\begin{tabular}{ll}
\hline Organization & $\begin{array}{l}\text { codify, sort, discriminate, display, favor, judge, organize, re- } \\
\text { late, systematize, order, weigh, adhere, generalize, alter, ar- } \\
\text { range, modify, synthesize, formulate, combine, integrate }\end{array}$ \\
\hline $\begin{array}{l}\text { Internalizing values (char- } \\
\text { acterization) }\end{array}$ & $\begin{array}{l}\text { act, listen, propose, serve, question, influence, solve, practice, } \\
\text { modify, discriminate, display, internalize, verify (least ad- } \\
\text { dressed through formal education). }\end{array}$ \\
\hline
\end{tabular}

The model below (Figure 1) is an adaptation from Goodhart, Verdi, and Kennedy (1991) which summarizes and simplifies the information given in Table 2. It provides a pictorial reference to the affective hierarchy, as well as, sampled verbs under each of them.

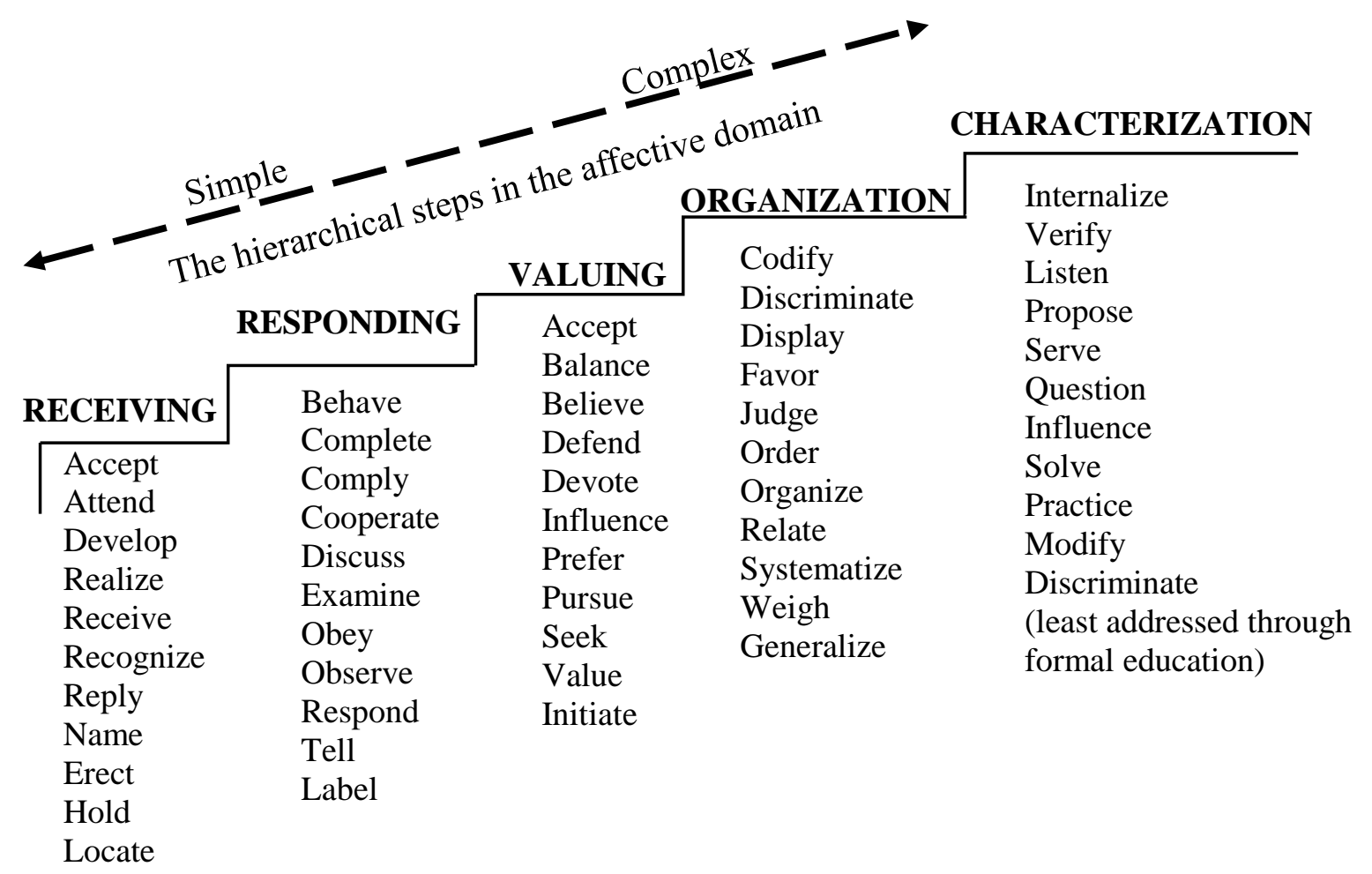

Figure 1: Affective hierarchy with sample verbs

\section{Theoretical framework}

Compared to the availability of theories for the other instructional domains (cognitive and psychomotor), theories that specifically focus on the affective domain are rather exiguous. The few that exist too seem quite cryptic and convoluted in terms of their systemization for practical applications. In this study, we adopt one such affective theory which, though dense, has extensive explanatory depth and cogent interpretive propensity for our present discussion, i.e. Mandler's (1972) theory of affect. It is a build-up on and refinement of extant constructivist views. The theory is potent to the extent that the affective domain is conceptualized as emotions-based and dwells on the proviso that the affective domain is principally inseparable from the other domains in practical terms (as showed earlier). It is useful therefore to evoke Wellington's (2010) definition of this domain as "the component of Bloom's taxonomy of educational objectives that involves the feeling and emotional side of learning and teaching; that is, enjoyment, motivation, drive, passion enthusiasm, inspiration" (pp. 135-136). According to Mandler, emotional experience consists of two factors, one physiological, the other cognitive. When an 
emotion occurs, the autonomic nervous system (ANS) is activated (the familiar "gut" response: a knot in the stomach, a quickened pulse, a heightened awareness of external stimuli). There is also a cognitive interpretation of this visceral arousal according to past experience or current situation. This interpretation makes sense of the physical agitation, evaluating the physiological evidence either positively or negatively. But, if this is what defines emotion, then what triggers the physiological reaction/cognitive interpretation in the first place? Mandler says that a major source of emotion is the interruption of an individual's schedule of activities or anticipated behavior. When our plans are interrupted, our ANS are activated and the physiological evidence is interpreted as emotional-excitement or frustration. In spite of the interruption, the individual will often persist in trying to complete the original plan. Completing an interrupted sequence is a positive, even a joyful experience.

Those are the main tenets of Mandler's theory of affect. With regard to this study, the theory helps to explain some key issues. Two of these key issues are highlighted. First of all, it explains the nature of many of the verbs that are itemized under the various affective categories in table two and in figure one. On the surface of it, verbs like "accept", "behave", "value", "discriminate", and so on may also seem like cognitive tasks. In light of this theory however, and in line with the inseparability claim among the domains discussed earlier, it is understandable that the cognitive tags are reappraisals of physiological responses triggered by the ANS. These verbs contain latent undercurrents of judgment which are informed by a person's subjective feelings. The theory thus offers a good lens through which the verbs in the lesson notes collected as field materials for this study are analyzed.

Secondly, the theory helps to explain how some of the affective objectives for the teaching of music are achieved. For example, one of the key values of teaching music, as evident in the general aims listed at the beginning of this paper, is to enhance critical thinking and imagination. In terms of recognizing beauty in music, imagination begins from internalizing certain musical structures (often culturally defined). According to Meyer (1956), these internalized structures help to create expectations when one listens to a new piece of music. The emotions experienced, or the level of enjoyment derived from the music comes when the expected tendencies are temporarily suspended or permanently blocked. In this respect, Meyer highlights what Mandler's theory opines in terms of emotions being the product of interrupted plans or intentions. A comparably recent support to this is what Juslin and Västfjäll (2008a, 2008b) describe as 'musical expectancy' (a process whereby an emotion is induced in a listener because a specific feature of the music violates, delays, or confirms the listener's expectations about the continuation of the music). Under the composition section of the music syllabus for example, pupils learn about the interplay between various musical elements and how they come together to form meaningful musical phrases which are further developed into musical forms. This, among other things, creates structures for musical expectancy which heightens the creative imaginations of pupils and influences their emotional reactions and hence tells significantly on their affective development. Further examples can be cited from the other sections of the music syllabus. The important point here therefore, is that Mandler's theory of affect provides a strong framework for interpreting the affective goals which are meant to be achieved through the teaching of music. 


\section{Participants}

\section{Method}

Thirty-two (32) basic schools in the Central Region of Ghana were involved in this study. Our study participants were the head-teachers in these schools, as well as, the Creative Arts teachers (with emphasis on music teachers in four schools where we found more than one Creative Arts teacher). In total therefore, 69 human subjects were involved in this study whose ages ranged from 22 to 58. As many as 29 (90.6\%) of the head-teachers and 31 (83.8\%) of the teachers were Christians, belonging to various orthodox and charismatic churches. Further demographic details of our study participants are provided in Table 3. It is verifiable from the table that gender imbalance clearly exists; fewer females are involved in the teaching of music and the Creative Arts.

Table 3: Demographic characteristics of study participants

\begin{tabular}{lccc} 
Characteristics & Head-teachers & Teachers & Total \\
\hline Gender & & & \\
Males & 26 & 23 & 49 \\
Females & 6 & 14 & 20 \\
Total & $\mathbf{3 2}$ & $\mathbf{3 7}$ & $\mathbf{6 9}$ \\
Age & & & \\
Below 30 & 1 & 8 & 9 \\
$31-40$ & 5 & 19 & 24 \\
$41-50$ & 14 & 3 & 21 \\
$51-60$ & 12 & $\mathbf{3 7}$ & 15 \\
Total & $\mathbf{3 2}$ & $\mathbf{6 9}$ \\
Years of service & (as head-teacher) & (overall teaching experience) & \\
Below 10 & 24 & 21 & 45 \\
$11-20$ & 8 & 13 & 21 \\
$21-30$ & - & 3 & 3 \\
Total & $\mathbf{3 2}$ & $\mathbf{3 7}$ & $\mathbf{6 9}$ \\
\hline
\end{tabular}

\section{Procedure}

In all, our study merged the strengths of different research designs. However, in terms of its main dominant purpose, it was largely descriptive as we sought to present the current status of the phenomenon in question (to describe the extent to which the affective domain is catered for through the teaching of music and dance in Ghanaian basic schools). We employed three main triangulation types (Neuman, 2003) to ensure authenticity and replicability. Firstly, triangulation of measures informed our use of multiple instruments for the collection of data. We used semi-structured interviews, observation, and collected pertinent materials as well for Qualitative Content Analysis (Schreier, 2013). The materials collected included copies of the Creative Arts teaching syllabus for Ghanaian Basic Schools (1-3, 4-6), lesson notes of Creative arts teachers and some recommended Creative Arts textbooks. Head-teachers in each of the 32 basic schools involved in this study were interviewed. The Creative Arts teachers in these schools gave us copies of their lesson notes which we photocopied and returned to them. We got up to 212 lesson notes in all. We also sat through selected Creative Arts lessons and observed the sequence of events; the nature of teacher-pupil interaction, the goals that were stressed in each lesson, the kind of evaluation that was done in each class, among others. Secondly, we consciously practiced triangulation of observers by undertaking our interviews and 
observation of lessons individually from a common pre-defined interview schedule and observation guide respectively. We later met as co-authors to compare notes and identify critical nexus points of convergence and divergence. The strength of this triangulation type, as Neuman (2003, p. 138) notes is that, "multiple observers or researchers add alternative perspectives, backgrounds, and social characteristics and will reduce the limitations". Thirdly, we covered the dictates demanded by triangulation of theory by employing two different theoretical models: one (Mandler's theory of affect) as the theoretical framework and the other (Krathwohl, Bloom and Massia's model of the affective domain) as the conceptual framework. Our selection of the 32 basic schools was done through the multi-stage cluster sampling approach (Sarantakos, 2005).

\section{Results and Discussion}

Considering the nature of data we sought for analysis and the research instruments we used (interviews and observation), it goes without saying that the feedback/response rate was very high. Our major observations are summarized in three main findings which we first enumerate, and then expatiate through the discussion.

1) Mismatch between curriculum goals/objectives, content, teaching activities and assessment procedures.

2) Inadequate number of teachers who are adequately trained to teach music at the basic schools.

3) Development of the affective domain is largely not emphasized through the teaching of music.

To begin with, we found a number of inconsistencies within the curricula materials that we analyzed. Appropriately, the predominantly affective general aims and objectives in the syllabus as stated in the introduction of this paper were supposed to have corresponding activities and content which would help achieve those goals. Unfortunately, that was often not the case. On page vii of the Creative Arts syllabus (1-3 \& 4-6), just a few pages after the general aims and objectives for the subject are stated, the following is written in bold typeface:

Note: "Practical Skills" must be given 80 per cent of the teaching and learning time to emphasise the point that Creative Arts is more toward the acquisition of practical skills at the school level. The remaining 20 per cent can be used for the theoretical aspects of Creative Arts such as, observing, listening, responding, talking, reporting, describing, brainstorming and discussion.

Out of the six general aims that are listed for the teaching of the subject, only one focuses on performance. This is because teaching music, for example, in the basic school is not necessarily to turn the pupils into performers (Dzansi-McPalm, 2004; Reimer, 1989/2003). It is to help them to develop the building blocks with which they can derive the most from the music that is experienced in their everyday activities. Urging teachers to devote up to $80 \%$ of teaching and learning time for practical skills is in direct contradistinction to the stated general aims. The emphasis on practical skills again shifts the focus of music teaching from achieving affective goals and enhancing affective wellbeing towards a more psychomotor-oriented subject. Furthermore, the music component of the Creative Arts syllabus has three main sub-divisions: Performance, Composition, and Listening and Observing. Of these three sections, it is only the Performance section that is meant to focus specifically on purely practical skills. These swings 
in the intentions stated in the syllabus (which is the main document for the teaching of the subject) are befuddling for the teachers who are supposed to handle the subject. For instance, our interviews showed that they clearly did not know what exactly to focus on and what to aim for in their teaching. A look at the objectives, content, activities and assessment procedures in the lesson notes we examined proved this point; out of the 212 lesson notes we examined, only $18(8.5 \%)$ were consistent from lesson objectives through to evaluation. The remaining $91.5 \%$ had various inconsistencies described in Table 4 . Because the exact cases are many and varied, we have presented only one instance to exemplify each of the points made for each of the three music aspects in the syllabus.

Table 4: Examples of observed inconsistencies in lesson notes

\begin{tabular}{|c|c|c|}
\hline Aspect & $\begin{array}{l}\text { Nature of objectives (By the end of the } \\
\text { lesson, the pupil will be able to:) }\end{array}$ & Nature of evaluation \\
\hline $\begin{array}{l}\text { Performance } \\
\text { (class 2, } 30 \text { mins) }\end{array}$ & $\begin{array}{l}\text { a) demonstrate how to dance kpanlogo } \\
\text { b) perform basic kpanlogo movement in } \\
\text { an ensemble setting }\end{array}$ & $\begin{array}{l}\text { Pupils draw the djembe } \\
\text { drum and colour it in } \\
\text { the exercise book }\end{array}$ \\
\hline $\begin{array}{l}\text { Composition } \\
\text { (class } 1,1 \mathrm{hr} \text { ) }\end{array}$ & $\begin{array}{l}\text { a) imitate some familiar sounds around } \\
\text { him/her eg. Bleat of goats } \\
\text { b) describe the differences in sound made } \\
\text { by birds/animals } \\
\text { c) create their own sound patterns with } \\
\text { variety of objects }\end{array}$ & $\begin{array}{l}\text { Pupils describe the } \\
\text { sound made by the fol- } \\
\text { lowing animals/birds in } \\
\text { their exercise books } \\
\text { a) cat = ( } \\
\text { b) cow = ( } \\
\text { c) dog = ( } \\
\text { d) bird = ( }\end{array}$ \\
\hline $\begin{array}{l}\text { Listening and ob- } \\
\text { serving } \\
\text { (class } 3,1 \mathrm{hr} \text { ) }\end{array}$ & $\begin{array}{l}\text { a) play the gong pattern in apatampa } \\
\text { b) play the apetia drum in apatampa } \\
\text { c) play the master drum in apatampa }\end{array}$ & $\begin{array}{l}\text { Pupils present apatampa } \\
\text { in an ensemble setting }\end{array}$ \\
\hline
\end{tabular}

In the first example, the objectives for the lesson, in line with the aspect (performance) require pupils to be able to carry out a performance by the end of the lesson. By the end of the lesson however, the pupils are rather expected to be able to "draw and colour a djembe drum". In the second example, three objectives are set in a composition lesson that require pupils in basic one to "imitate", "describe", and "create" various sound patterns. In the end however, these pupils are required to write a description of specified animal sounds in their exercise books. As if that was not problematic enough, the other two objectives are clearly left unexamined. In example three, there are three objectives which all require basic three pupils to play various instruments in an apatampa ensemble, although the aspect being treated is not "Performance" but "Listening and Observing". For the evaluation, pupils are expected to present apatampa in an ensemble setting (whatever that means). It is exactly these inconsistencies that give the impression that the teachers are not very competent in what they are doing (see Boyle \& Radocy, 1987). Justifiably so, some of the lessons we observed were very stultifying and were a pointer to teacher incompetence in the teaching of music at the basic level. This prompted us to enquire more about the caliber of the teachers.

Our interviews with the heads of the schools showed that many of the teachers $(82 \%)$ had not received adequate training in the Creative Arts (particularly in music) to be able to efficiently handle the subject. In four of the schools, the music teachers there were teachers of other subjects before the whole new Creative Arts program was introduced in 2007 and no inservice training was organized to get these teachers equipped for their new task. The head- 
teachers in the schools relied on teachers who showed some form of talent in the arts or singing to teach this course. Therefore, the teachers in question were only able to do what their abilities would allow them to perform. In the case where a teacher was more visual arts inclined, s/he would teach those aspects of the syllabus and ignore anything else. As one head-teacher admitted in our interview with her, "it is a problem, but we are not too worried about it [...] because, you know, because it is not examined [...] I mean externally". The interview showed that although the head-teachers are aware of the problem, they are not too bothered about it for the express reason that the students do not have to account for it in any standardized external examination. In four of the schools, we found two different teachers for the Creative Arts; one for music in each case and one for the other aspects of the subject. The remaining $18 \%$ of the teachers who had some training received this training in their respective Colleges of Education. However, they admitted that the content of the basic school music was quite different from what they had been trained in college to teach. The music lessons we observed were mostly theoretical and involved abstract concepts taught without the use of appropriate pedagogy or teaching learning materials. When asked, teachers complained much about the absence of resources such as graded music books and musical instruments in the schools. A few of the resourceful teachers played musical samples from their laptops and showed pictures of some instruments to illustrate some of the points discussed in class. This theoretical, and rather abstract, presentation of musical concepts to pupils stresses the cognitive domain where recall of memorized facts dominates the learning process. It depicts the kind of pedagogical delivery regarded by Kwami (1994) as a contributory factor to the decline of music education in Ghana and Nigeria.

The analysis of the verbs used in the lesson notes also showed a different finding than what we expected. From the general aims and objectives listed in the Creative Arts syllabus, we had expected to find verbs that were more inclined towards the affective domain as exemplified in Table 2 and in Figure 1. In all, 536 verbs were present in the 212 lesson notes collected. Many of the verbs were repeated. In fact, the teachers used a small repertoire of behavioral verbs that kept recurring (a visual display of the verbs is given in the word-cloud in Figure 2).

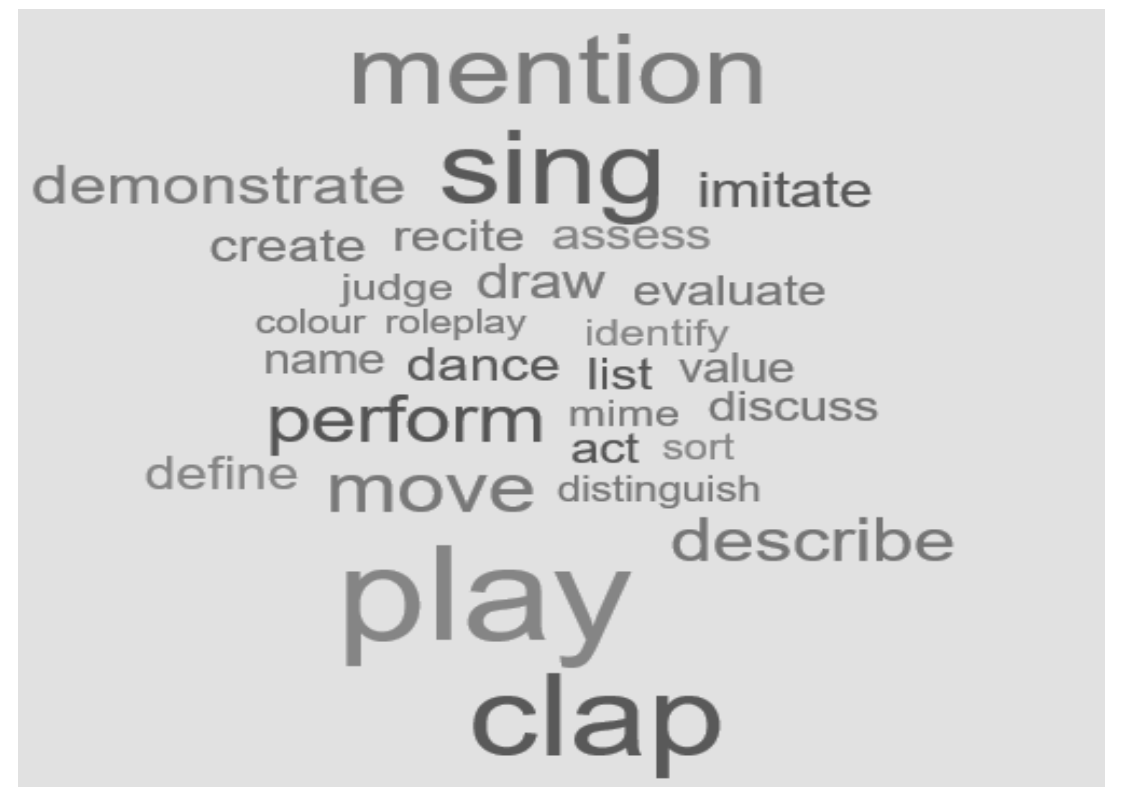

Figure 2: A visual display of behavioural verbs used in lesson notes 
The size of the writing in Figure 2 is commensurate with the frequency of occurrence; the bigger the size, the more that particular verb was repeated. Some of the lessons had only one objective while others had as many as four objectives. In all, we found that majority of the verbs $(58 \%)$ were within the psychomotor domain. $33 \%$ were within the cognitive domain and only $9 \%$ of the verbs specified affective outcomes. A pictorial representation of the distribution of verbs with their corresponding percentages within the three domains is shown in Figure 3.

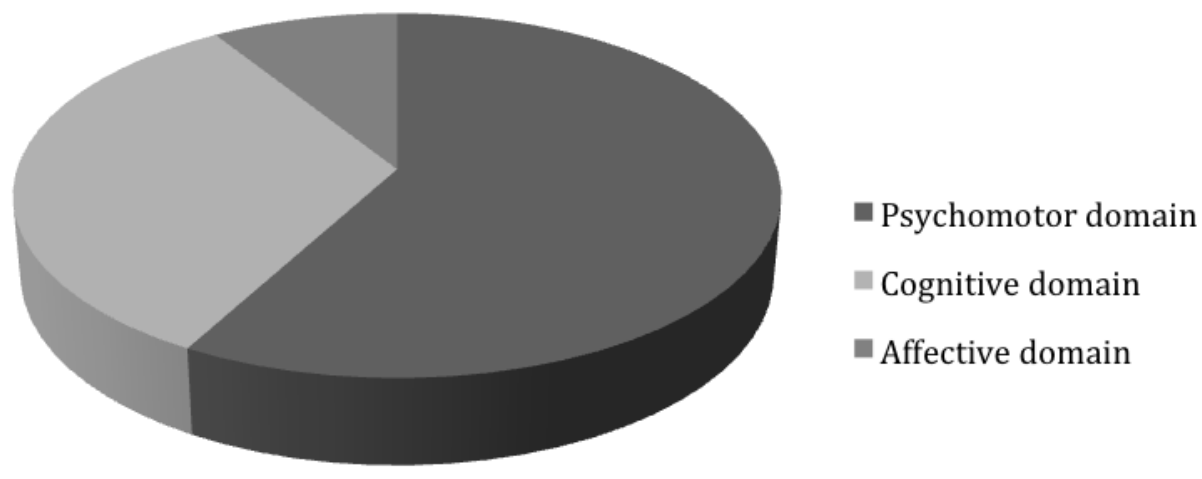

Figure 3: Distribution of verbs within the three domains

This outcome, with the lower emphasis on the affective domain is indicative of poor affective wellbeing. The results provide further justification to the claim of Wellington (2010) that, "the affective domain has often been neglected by many teachers" (p, 136). A probable explanation that Wellington offers for this observation is that, as behaviorism became more dominant in educational psychology, affect was ruled out by some educators. Equally, other developments in psychology led to humans being viewed through a model of "input-processoutput', with thinking processes likened to that of a computer. Through the lens of our theoretical framework, it can be argued that these percentages are not in themselves, any issues of concern considering the practical inseparability in the domains. However, it is when closer attention is given to the evaluation of these objectives that it becomes apparent that affective goals are not the primary concern in the teaching of music in the schools investigated.

In our case, a form of explanation for this distribution (with the emphasis on performance) was also found in the interviews. For most of the head-teachers, music meant singing, playing an instrument, clapping, tapping or dancing. In one of the schools for example, the weekly "worship" session that the pupils did together every Wednesday morning, sufficed for the music lessons. There was also very little or no consistency at all in terms of uniformity in content or timeline between the different schools. In other words, each school seemed to have its own pace and discretion when it came to the teaching of music. This situation is similar to what Flolu and Amuah (2003) report to be the nature of music education in Ghanaian basic schools before the first music syllabus for the basic schools was introduced in 1959. It is regrettable that after all these years, the situation has only ebbed. This lack of uniformity in purpose, focus or structure might just be due to the fact that, there is no overriding and defining philosophy for the practice of music education in Ghanaian basic schools. 


\section{Conclusion}

Abeles et. al. (1995) enthusiastically make two profound arguments about the importance of teaching music:

a) "every child should have a general, broad musical experience before embarking on his or her choice of specialized activities. Without it, most students would not be able to make intelligent choices" (p. 278).

b) "Music and the arts are one of the most significant manifestations of the ability of human beings to think and to aspire restlessly for something more than survival. Music has much to do with what makes us different from the animals and marks us as human" (p. 66).

The basis of their arguments is entrenched in the conviction that through the teaching of music, cherished values (mostly affective such as the imperative to make value judgments) which are hardly attainable through the teaching of other subjects are carefully nurtured and developed. In that sense, music education adds to the health and wellbeing of the individual as they go through the educational system by filling the gap which the other subjects so often ignore - the affective domain. As Reimer (2009) stresses, a justification for the teaching of music must be based on the nature and true value of the subject. This paper has shown that music has a lot to offer, particularly with respect to developing the affective domain. The literature that we parsed and our theoretical framework clearly point to the fact that the development of the affective domain is the overarching mandate of music teaching and learning. The achievement of this educational goal, however, does not come easily or automatically. It is an arduous task that must be consciously planned and systematically implemented. The data we collected and analyzed unambiguously point to the fact that the role of music in enhancing the affective wellbeing of students is far from being achieved. Granted that quality education is one which makes equitable provision for the development of all the domains, it is reasonable to conclude that the Ghanaian basic educational system needs reforms. There is too much emphasis on cognitive and psychomotor domains to the detriment of the affective aspect. Such an educational system produces people who know and understand (theoretically) when something needs to be done to improve a situation. But, most often, they show the lack of moral zeal or obligatory urgency to act. We recommend, based on the findings that educational planners in Ghana should have a critical re-assessment of the music program in basic schools in terms of clearly defining its mandate through a sound philosophy, reviewing curricula materials, and providing the requisite training for music teachers. 


\section{References}

Abeles, F. H., Hoffer, C. R., \& Klotman, R. H. (1995). Foundations of music education (2 ${ }^{\text {nd }}$ ed.). New York: Schirmer Books.

Anderson, L., \& Krathwohl, D. (Eds.). (2001). A taxonomy for learning, teaching, and assessing: A revision of Bloom's taxonomy of educational objectives. New York: Longman.

Addo, A. O. (1992). A survey of music teaching strategies in Ghanaian elementary schools as a basis for curriculum development. Music Education: Sharing Musics of the World (pp. 267-273). International Society for Music Education.

Akrofi, E. A. (1982). The status of music education programs in Ghanaian public schools. Unpublished doctoral thesis, University of Illinois, Urbana-Champaigne.

Anamuah-Mensah, J., Asabere-Ameyaw, A., \& Dennis, S. (2007). Bridging the gap: Linking school and the world of work in Ghana. Journal of Career and Technical Education, 23(1), 133-152.

Aristotle. (1984). The politics. Translated and with an introduction, notes and glossary by Carnes Lord. Chicago: University of Chicago Press.

Barlow, R. (1977). Health and economic development: A theoretical and empirical review. Michigan: University of Michigan Press.

Bilderback, B., \& Woelfel, K. (2012). Perspectives on coastal Ghana's musical and social patterns: 'One' is not where we think it is but it is always where it should be. Journal of Pan African Studies, 5(8), 22-40.

Bloom, B.S. (1956). Taxonomy of educational objectives: Handbook 1. Cognitive domain. New York: David McKay.

Boyle, J. D. \& Radocy, R. E. (1987). Measurement and evaluation of musical experiences. New York: Schirmer Books.

Brand, A. G. (1983). Hot cognition: Emotion and writing behavior. Paper presented at the annual meeting of the Conference on College Composition and Communication. Detroit, pp. 17-19.

Chauhan, S. S. (1991). Advanced educational psychology. Vikas: Stanley Thornes Publishers.

Derry, S. J., \& Murphy, D. A. (1986). Designing systems that train learning ability: From theory to practice. Review of Educational Research, 56, 1-39.

Dzansi-McPalm, M. (2004). Playground music pedagogy of Ghanaian children. Research Studies in Music Education, 22, 83-92.

Flolu, J., \& Amuah, I. R. (2003). An introduction to music education in Ghana for universities and colleges. Accra: Black Mask Limited.

Flolu, E. J. (2000). Re-thinking arts education in Ghana. Arts Education Policy Review, 101(5), 25-29.

Fritz, T., Jentschke, S., Gosselin, N., Sammler, D., Peretz, I., Turner, R., Friederici, A.D., Koelsch, S. (2009), Universal recognition of three basic emotions in music. Current Biology, 19, 573-576.

Goodhart, F., Verdi, P., \& Kennedy, S. (1991). Assuring quality in health education. Paper presented at the Mid-Atlantic College Health Association, MD, Baltimore.

Jager, C. (2009). Affective ignorance. Erkenntnis, 71(1), 14-32.

Juslin, P. N., \& Västfjäll, D. (2008a). Emotional responses to music: The need to consider underlying mechanisms. Behavioral and Brain Sciences, 31, 559-575. 
Juslin, P. N., \& Västfjäll, D. (2008b). All emotions are not created equal: Reaching beyond the traditional disputes. Behavioral and Brain Sciences, 31, 600-621.

Krathwohl, D. R., Bloom, B. S., \& Masia, B. B. (1964). Taxonomy of educational objectives: Handbook 2. Affective domain. New York: David McKay.

Kwami, R. (1994). Music education in Ghana and Nigeria: A brief survey. Africa, 64(4), 544554.

Levitin, D. J. \& Tirovolas, A. K. (2009). Current advances in the cognitive neuroscience of music. The year in cognitive neuroscience, 1156, 211-231.

Mandler, G. (1972). Helplessness: Theory and research in anxiety. In C. D. Spielberger (Ed.), Anxiety: Current trends in theory and research (pp. 359-374). New York: Academic Press.

McLeod, S. (1987). Some thoughts about feelings: The affective domain and the writing process. College Composition and Communication, 38(4), 426-435.

Meyer, L. B. (1956). Emotion and meaning in music. Chicago: University of Chicago Press.

Miles, E. (2005). Tune your brain: Using music to manage your mind, body and mood. New York: iUniverse, Inc.

Mohn, C., Argstatter, H., \& Wilker, F. W. (2010). Perception of six basic emotions in music. Psychology of Music, 1-15.

Ministry of Education (2007). Creative Arts (1-3) syllabus for primary schools. Accra: MOE. Ministry of Education (2007). Creative Arts (4-6) syllabus for primary schools. Accra: MOE.

Murphy, R., \& Fautley, M. (2015). Music education in Africa. British Journal of Music Education, 32(3), 243-245.

Neuman, W. L. (2003). Social research methods: Qualitative and quantitative approaches. England, Pearson Education, Inc.

Norman, Donald. (1981). Twelve Issues for Cognitive Science. In D. A. Norman (Ed.), Perspectives on Cognitive Science (pp. 265-295). Norwood, NJ: Ablex.

Otchere, E. D. (2015). Music teaching and the process of enculturation: A cultural dilemma. British Journal of Music Education, 32(3), 291-297.

Otchere, E. D. (2014). Reconsidering music in tertiary education: An empirical basis. Tertiary Education Series, 7(1), 1-24.

Otchere, E. D. (2013). Interpreting encoded emotions in musical scores for performance: A synergy of corroborating knowledge sources. In E. Johnson (Ed.), Script: Understanding, analysis, interpretation for performance (pp. 39-52). Cape Coast: University of Cape Coast Press.

Otchere, E. D. (2013a). On the value of music: A basis for philosophy and advocacy for music education. The Parnassus, 9(1), 86-101.

Otchere, E. D. (2013b). Music and factual recall: Towards consolidating the evidence. The Parnassus, 9(2), 245-262.

Pacansky-Brock, M. (2012). Best practices for teaching with emerging technologies. New York: Routledge.

Rainbow, B. (1989). Music in educational thought and practice: A survey from 800 BC. Wales: Boethius Press

Reimer, B. (2009). Seeking the significance of music education; essays and reflections. Illinois: Rowman \& Littlefield Publishers.

Reimer, B. (2003). A philosophy of music education: Advancing the vision. Englewood Cliffs, NJ: Prentice Hall. 
Reimer, B. (1989). A philosophy of music education (second edition). Englewood Cliffs, NJ: Prentice Hall.

Richardson, C. P. (2003). Negotiating borderlands: A study of music teaching and learning in Ghana, West Africa. Music Education Research, 5(3), 275-291.

Sarantakos, S. (2005). Social research ( $3^{\text {rd }}$ ed). New York: Palgrave Macmillan

Schreier, M. (2013). Qualitative content analysis. London: SAGE.

Simpson, E. (1966). The classification of educational objectives (Report No. OE5-85-104). Washington, DC: United States Office of Education.

Tomkins, S.S. (1963). Affect, imagery, consciousness. Vol. 2. The negative affects. New York: Springer.

Valentine, G., Jayne, M. \& Gould, M. (2014). The proximity effect: The role of the affective space of family life in shaping children's knowledge about alcohol and its social and health implications. Childhood, 21(1), 103-118.

Vygotsky, L. (1962). Thought and language. Trans. E. Hanfmann and G. Vakar. Cambridge: MIT Press.

Wellington, J. (2010). More than a matter of cognition: An exploration of affective writing problems of post-graduate students and their possible solutions. Teaching in Higher Education, 15(2), $135-150$.

Winter, L. Moss. M. S. and Hoffman, C. (2009). Affective forecasting and advance care planning: Anticipating quality of life in future health status. Journal of Health Psychology, 14(3), 447-456. 